\title{
Feeding activity and influence of intraspecific competition on zooplankton communities by jundiá (Rhamdia quelen Quoy and Gaimard, 1824) in laboratory
}

\author{
Brandão-Gonçalves, L. * and Sebastien, NY. \\ Universidade Estadual do Oeste do Paraná, Programa de pós-graduação strictu sensu em Recursos Pesqueiros e \\ Engenharia de Pesca, Laboratório de Ecotoxicologia e Biomanipulação, Rua da Faculdade, 645 - Caixa Postal 320 , \\ Jd. Santa Maria, Toledo, PR, Brazil \\ *e-mail: lucasbrandaog@yahoo.com.br
}

Received August 28, 2012 - Accepted October 26, 2012 - Distributed November 29, 2013

(With 3 figures)

\begin{abstract}
Experiments were designed to determine if the juvenile forms of jundia (Rhamdia quelen) exhibit selectivity feeding on zooplanktonic organisms and the influence of intraspecific competition on the diet. The fish were maintained in 5000-L containers, and after seven days from birth, they were acclimated in experimental units with different densities and supplied with water containing plankton (natural), where they remained for $24 \mathrm{~h}$ in the environment with food. In the first seven days at densities of 5 and 10 fish. $\mathrm{L}^{-1}$, the fish selected the Rotifera more intensely, and at densities of 20 and 40 fish. $\mathrm{L}^{-1}$, the Cladocera were more selected. At 14 days of age, the Cladocera were the most selected for all densities of fish. At 21 days of age, the juvenile forms of jundia maintained a preference for Cladocera, and there was an increase in the capture of Copepoda at a density of 40 fish. $\mathrm{L}^{-1}$. At 28 days of age, the Cladocera were the most captured at densities of 5 to 20 fish. $\mathrm{L}^{-1}$, and the consumption of copepods increased at a density of 40 fish. $\mathrm{L}^{-1}$. The juvenile forms of Rhamdia quelen showed a high feeding preference for Cladocera at all the ages tested (7, 14, 21 and 28 days), but the density of fish per litre influenced the capture of the preferential food. This study showed that the juvenile forms of jundia had a more rapid response to the presence of food at densities of more than 10 fish.L $\mathrm{L}^{-1}$, and that at higher densities the fish decreased interactions of territorial defense and formed schools, which allowed the foraging of zooplanktonic organisms, larger in size, more agile and of greater energy gain, such as the Cladocera and copepods.
\end{abstract}

Keywords: feeding selectivity, stocking density, jundia, zooplankton.

\section{Atividade alimentar das formas jovens de jundiá (Rhamdia quelen Quoy and Gaimard, 1824) sobre organismos zooplanctônicos, e a influência da competição intra-específica na dieta em laboratório}

\section{Resumo}

Delineou-se um experimento com o objetivo de analisar se as formas jovens de jundiá (Rhamdia quelen) realizam seletividade alimentar sobre os organismos zooplanctônicos, e como a dieta pode ser influenciada pela competição intra-específica. Os peixes foram mantidos em caixas de $5000 \mathrm{~L}$ e após sete dias do nascimento foram acondicionados nas unidades experimentais em diferentes densidades e abastecidos com água contendo plâncton (natural), permanecendo 24 horas no meio com alimento. Nos primeiros sete dias em densidades de 5 e 10 peixes/L, os peixes selecionaram mais intensamente os Rotifera, nas densidades de 20 e 40 peixes/L os Cladocera foram os mais selecionados. Aos 14 dias de idade os Cladocera foram os mais selecionados em todas as densidades de peixes. Aos 21 dias de idade as formas jovens de jundiá mantiveram a preferência por Cladocera e houve um aumento na captura de Copepoda na densidade de 40 peixes/L. Com 28 dias de idade os Cladocera foram os mais capturados nas densidades de 5 a 20 peixes/L, o consumo de Copepoda aumentou na densidade de 40 peixes/L. As formas jovens de Rhamdia quelen apresentaram uma alta preferência alimentar por Cladocera em todas as idades testadas ( $7 ; 14 ; 21$ e 28 dias), no entanto, a densidade de peixes por litro têm influência sobre a captura do alimento preferencial. Verificou-se neste trabalho, que as formas jovens de jundiá apresentaram uma resposta mais rápida a presença de alimento em densidades superiores a 10 peixes/L, nas maiores densidades os peixes diminuíram as interações de defesa de território e formaram cardumes, o que permitiu um forrageamento de organismos zooplanctônicos maiores, mais ágeis e de maior lucro energético como Cladocera e Copepoda.

Palavras-chave: seletividade alimentar, densidade de estocagem, jundiá, zooplâncton. 


\section{Introduction}

Currently, there is a growing interest in information on the various aspects of the trophic ecology of fish, where it is increasingly necessary to know what the role is of species in their environment, that is, how they interact with the abiotic environment and other organisms, to thereby understand the functioning of ecosystems, with the aim of preserving them or managing them adequately (Lowe-McConnell, 1999). Thus, knowledge about fish behaviour, feeding sources utilised by the fish and existence or not of feeding selectivity is an important factor in the ecological study of species (Zavala-Camin, 1996) and a tool for biotechnological applications. Moreover, information about the intensity of food intake can be useful for the complementation of studies aimed at detecting competitive interactions between species or distribution of resources between them (Hahn and Delariva 2003).

Sharing of resources among fish has received considerable attention on the part of many researchers (LoweMcConnell, 1999; Russo et al., 2004; Crippa et al., 2009; Dias and Fialho, 2009; Brandão-Gonçalves et al., 2010). However, one question that has been considered little in these studies are changes in feeding habit according to availability of food, and in the choice of food according to its quality (Esteves and Aranha, 1999).

According to Zavala-Camin (1996), the presence of a particular type of food in the digestive contents of fish does not necessarily mean that it is the preferred food, because the majority of fish show plasticity in their diet, considering that they choose new prey depending on growth, moving to other habitats and seasonal and annual availability, or that they display active selection depending on individual preferences for particular foods (Roche and Rocha, 2005). Most times, this preference is conditioned to availability in the environment (Weatherley, 1972).

Relatively small individuals such as fish larvae are important consumers in aquatic ecosystems (SipaubaTavares, 1993), where in this environment, it is believed that the size of organisms can be a determinant factor in the behavior of the food chain, ecological efficiency, transfer of energy and type of organisms of highest trophic levels (O'Gorman et al., 2010). In general, fish larvae feed on zooplankton (Soares et al., 2000; Luz and Zaniboni, 2002; Makrakis et al., 2005; Russo and Hahn, 2006), during this phase, fish can reach sufficient abundances to cause reductions in density of zooplankton populations in water bodies (Dettmers and Stein, 1992; Devries and Stein, 1992; Shahady, 1993; Qin and Culver,1996).

This increase in abundance of fish and/or reduction of quantity of prey can produce competition by the exploitation of these food resources, where this interaction between individuals is caused by a similar requirement for a resource, leading to a reduction in survival, growth and/or reproduction of at least some of the competing individuals (Begon et al., 2006).
Competition for food can influence diets because of the environment from alterations in abundance levels of resources, modifications in distribution and behaviour by interactive segregation (Arcifa et al., 1991; Bohn and Amundsen, 2001). According to Gerking (1994), the feeding behaviour of a fish should be observed under varied conditions, including supply feeding, because a specialist can become a generalist, if a food source changes.

In works on fish farming, various authors have studied the effects of intraspecific interactions of fish larvae and juveniles, such as competition for food and space (Jobling, 1994; Hecht and Uys, 1997; Piaia and Baldisserotto, 2000). Stickney (1994) noted that stocking density influences the behaviour of fish, leading to an increase or decrease in competitive interactions, directly depending on the quantity of individuals in the same place.

The cultivation of fish larvae in the laboratory allows more detailed investigations of the habits and feeding preferences and behaviour of larvae and observations on their tolerance to different environments (Sipauba-Tavares, 1993). Therefore, the aim of the present study was to determine the feeding behaviour of juvenile forms of Rhamdia quelen Quoy and Gaimard, 1824, at different stocking densities, as they grow, to see if intraspecific competition leads to changes in diet, providing information on the existence of feeding selectivity in relation to natural feeding (zooplankton), and if this factor can be influenced by the quantity of competing fish in one place.

\section{Materials and Methods}

The study was carried out in the laboratory at the "Universidade Estadual do Oeste do Paraná" (20022'S and 53044'W), during two months between February to March 2011.

The larvae of jundia (Rhamdia quelen) were obtained through induced reproduction of females maintained on site. The zooplanktonic communities were isolated from fish ponds using a $60 \mu \mathrm{m}$ mesh plankton net, and maintained in laboratory culture.

The juvenile fish were maintained in 5000-L water tanks, where they were transferred to experimental units every seven days. Four feeding selectivity experiments were carried out with jundias at different ages: 7, 14, 21 and 28 days.

Each experiment involved a battery with 12 small containers (1 L each) distributed in a complete randomised experimental design with four treatments of different stocking densities (DS) $\left(\mathrm{DS} 1=5\right.$ fish.L $\mathrm{L}^{-1}, \mathrm{DS} 2=$ 10 fish. $\mathrm{L}^{-1}, \mathrm{DS} 3=20$ fish. $\mathrm{L}^{-1}$ and DS4 $=40$ fish. $\left.\mathrm{L}^{-1}\right)$ and three repetitions each.

The juvenile forms of fish were maintained fasting for $24 \mathrm{~h}$ and then collected from the water tanks and placed in containers supplied with the environment offered as food (water with zooplankton). After being distributed (according to treatments), they remained in the aquariums for $24 \mathrm{~h}$. The fish were then anesthetised with benzocaine $\left(25 \mathrm{mg} . \mathrm{L}^{-1}\right)$ solution for $30 \mathrm{~min}$ in order to 
avoid regurgitation and then fixed in $10 \%$ formalin. The water from the containers was also collected (1 litre) after removal of the juvenile forms, filtered with a $60 \mu \mathrm{m}$ mesh plankton net, placed in glass flasks and fixed in $10 \mathrm{~mL}$ of $10 \%$ formalin.

The density of planktonic organisms present in the tanks were determined by light microscopy, before their offering as food, where a subsample $(2 \mathrm{~mL})$ was used for counting. The individuals were quantified using a Sedgwick-Rafter type counting chamber, the counts and identification of organisms were performed under a stereomicroscope and light microscope with $40 \mathrm{X}$ and $100 \mathrm{X}$ magnifications. The specimens were identified using the specialised literature (Rocha and Matsumura-Tundisi, 1976; Koste, 1978; Segers, 1995; Elmoor-Loureiro, 1997).

The digestive tracts of five juvenile forms of fish per treatment were removed under a stereomicroscope with the help of a scalpel and then opened for visualisation and counting of food items under a light microscope. Feeding selectivity was determined according to Paloheimo (1979) per environment using the following formula: NFRi $=($ ri/pi $) /($ ri $/$ pi $)$, which was calculated based on the relation between the proportion of prey present in the diet of the predator (ri) and the proportion of prey in the environment (pi).

To determine the existence or not of selectivity, the index obtained was compared to the reference value, which is equal to $1 / \mathrm{n}$, where $\mathrm{n}$ is the number of different food items in the environment. NFRi $=1 / n$ is considered without selection; if NFRi $>1 / \mathrm{n}$, selection is positive; and if NFRi $<1 / \mathrm{n}$, selection is negative.

Based on the null hyptothesis $H_{0}$, with the presupposition that: "The juvenile forms of Jundia (Rhamdia quelen) at different ages and stocking densities do not display feeding selectivity on zooplanktonic organisms," the data obtained were submitted to factorial analysis of variance (factorial ANOVA, $p>0.05$ ), taking into consideration the age of the fish, DS and zooplanktonic groups preyed upon as categorical predictors (factors) and NFR values as the dependent variable.

In the case of statistical differences, Tukey's test was used at $5 \%$ level of probability. The assumptions of homocedasticity (Levene test) and normality (ShapiroWilk test) were evaluated. When these assumptions were not met, these statistical analyses were performed with $\log (\mathrm{x}+1)$ transformed data, and the analysis and the tests were carried out in the STATISTICA 7 computational program.

\section{Results}

A total of 240 juvenile forms of Rhamdia quelen at different stages of development were desiccated (Figure 1), andx the mean size and weight of the individuals were determined (Table 1).

The organisms present in the environment offered as food were identified and classified to the species level. During the analyses of the stomach contents of the fish,
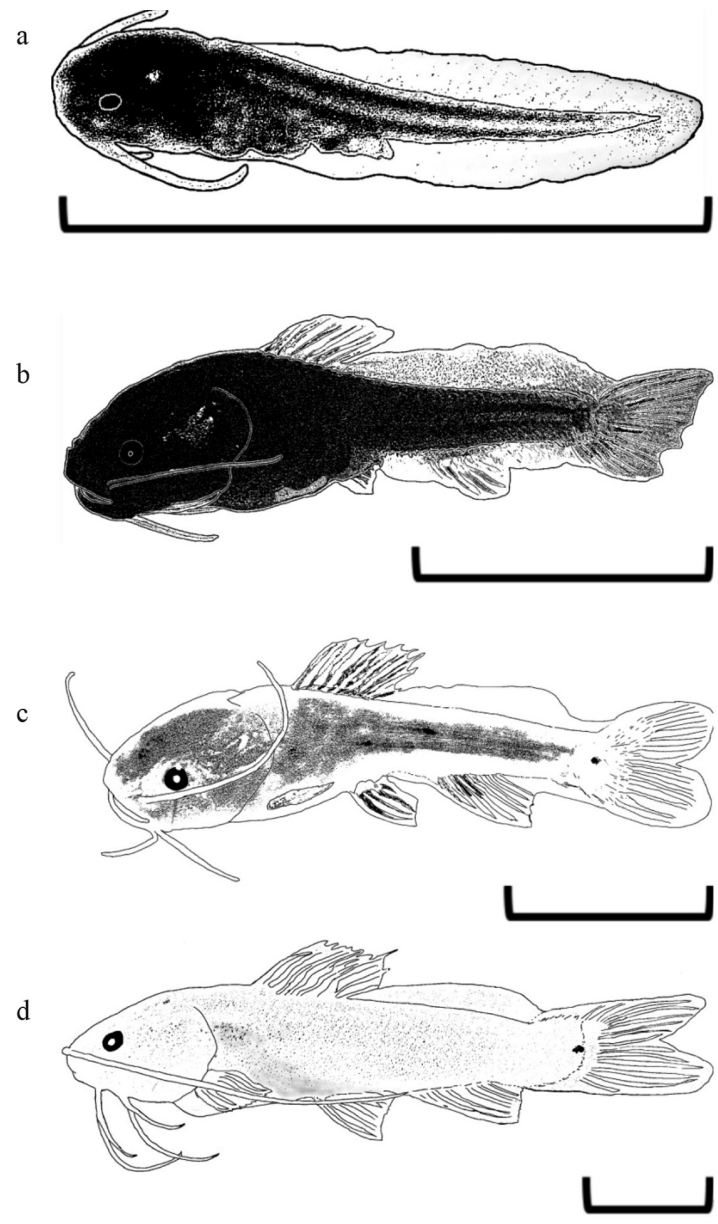

Figure 1 - Juvenile forms of Rhamdia quelen utilised in the feeding selectivity and competition experiments, in the period of February to March 2011 (a- 7 days of age; b- 14 days of age; c- 21 days of age; $d-28$ days of age). $B a r=0.5 \mathrm{~cm}$.

the zooplanktonic species closely associated were summarised and represented to the genus level due to the difficulty in the differentiation of these when present in the digestive tracts, and thus, the environment contained 12 food items, where the majority were copepods in the form of naupliii and Calanoida copepodid (Table 2). Figure 2 displays the feeding selectivity index (NFR) for

Table 1 - Age, quantity, mean size (MS.) and mean weight (MW) of individuals of Rhamdia quelen utilised in feeding selectivity and competition experiments $(\mathrm{SD}=$ standard deviation).

\begin{tabular}{llllll}
\hline $\begin{array}{l}\text { Speci- } \\
\text { mens }\end{array}$ & $\begin{array}{l}\text { Age } \\
\text { (days) }\end{array}$ & $\begin{array}{l}\text { MS } \\
\text { (cm) }\end{array}$ & SD & MW (g) & SD \\
\hline 60 & 7 & 0.5 & 0.0619 & 0.0018 & 0.0001 \\
60 & 14 & 1.1 & 0.0996 & 0.0255 & 0.0020 \\
60 & 21 & 1.6 & 0.0783 & 0.0559 & 0.0060 \\
60 & 28 & 2.6 & 0.0854 & 0.2479 & 0.0403 \\
\hline
\end{tabular}




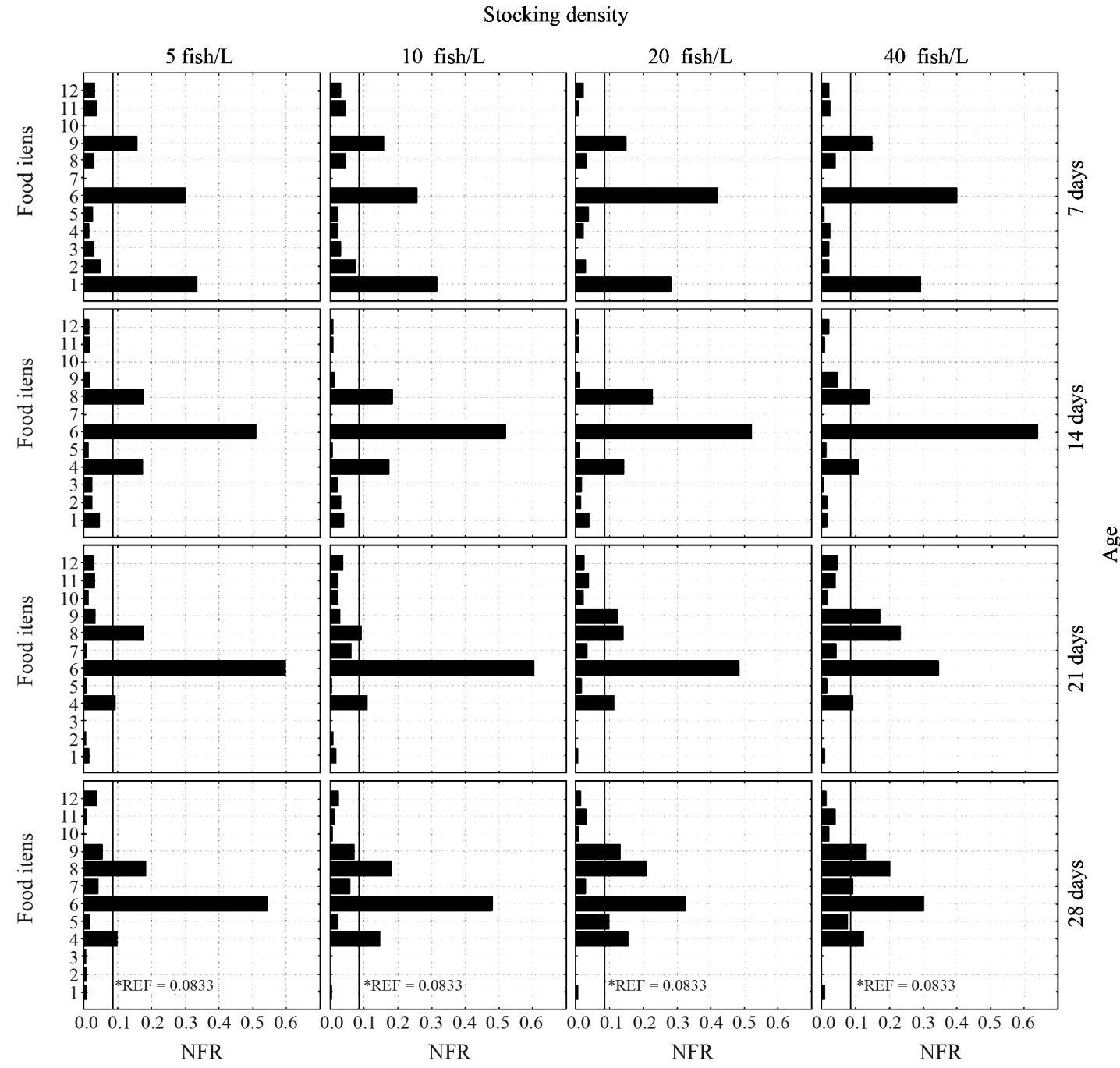

Figure 2 - Feeding selectivity index (NFR) of food items (species) consumed by Rhamdia quelen at different ages and stocking densities, where NFR values equal to or greater than the reference (REF $=0.0833)$ indicate positive selection $(1$ Brachionus spp.; 2- Lecane spp.; 3- Lepadella spp.; 4- Diaphanosoma brevireme; 5- Ceriodaphnia silvestrii; 6- Moina spp.; 7 Argyrodiaptomus furcatus; 8- Calanoida copepodid ; 9- Calanoida nauplii; 10- Thermocyclops decipiens; 11- Cyclopoida copepodid ; 12- Cyclopoida nauplii).

each zooplanktonic species consumed in each experimental unit.

Factorial analysis of variance demonstrated that there was an interaction between the factors: age of fish, stocking density and group preyed upon (ANOVA, $\mathrm{F}=14.94$; $\mathrm{p}<0.05$ ) (Table 3). Tukey's test detected 17 significant differences between the means of NFR of each group preyed upon by $R$. quelen at different ages and stocking densities. Based on these results, a scale was devised for the level of consumption of each item depending on intensity of predation.

The above scale was formulated based on the grouping of the means determined by Tukey's test in intervals of values, where these intervals distributed in classes (levels), by the application of Sturges' formula, according to which: $K=1+3.22\left(\log _{10} n\right)$, where $K=$ number of levels and $n=$ number of observations. Having defined the number of levels, the total range of the means was divided by $K$, resulting in the interval of the values which were allocated at each level (Table 4).

The juvenile forms of $R$. quelen at seven days of age showed the highest selectivity indices for the group of Rotifera at densities of 5 and 10 fish. $\mathrm{L}^{-1}$ (consumption level "c" and "b," respectively) (Figure 3 ). The Cladocera were the most consumed (consumption level "b") at densities of 20 and 40 fish. $\mathrm{L}^{-1}$, but Calanoida naupliii were still positively selected in all experimental units with more than 20 fish.L $L^{-1}$ (Figure 2). In the gastrointestinal contents of the larvae at this age, Brachionus spp. predominated in the treatments with 5 and 10 fish. $\mathrm{L}^{-1}$ and Moina spp. in the treatments of 20 and 40 fish. L $^{-1}$ (Figure 2). 
Table 2 - Mean abundance of zooplanktonic organisms present in the environments offered as food for the juvenile forms of Rhamdia quelen.

\begin{tabular}{lc}
\hline Items & $\begin{array}{c}\text { Abundance } \\
(\mathbf{\%})\end{array}$ \\
\hline Rotifera & 16.82 \\
Brachionus spp. Pallas, 1766 & 13.82 \\
Lecane spp. Nitzsch, 1827 & 2.29 \\
Lepadella spp. Bory of St. Vincent, 1826 & 0.71 \\
Cladocera & 27.05 \\
Diaphanosoma brevireme Sars, 1901 & 10.67 \\
Ceriodaphnia silvestrii Daday, 1902 & 1.59 \\
Moina spp. Baird, 1850 & 14.80 \\
Copepoda & 56.12 \\
Calanoida & 46.59 \\
Argyrodiaptomus furcatus Sars, 1901 & 6.45 \\
Calanoida copepodid & 12.54 \\
Calanoida nauplii & 27.60 \\
Cyclopoida & 9.54 \\
Thermocyclops decipiens Kiefer, 1929 & 2.15 \\
Cyclopoida copepodid & 3.01 \\
Cyclopoida nauplii & 4.38 \\
\hline
\end{tabular}

The Cladocera group was the most consumed by the jundia larvae at 14 days of age, showing the highest NFR values and consumption level "a" in all experimental units (Figure 3). The species most consumed was Moina spp. (Figure 2), where those positively selected were: Moina spp., Diaphanossoma brevireme and Calanoida copepodid, at all densities of fish examined.

The preference for the Cladocera group persisted for the larvae with 21 days of age, at densities of 5, 10 and 20 fish. $\mathrm{L}^{-1}$ (level "a," see Figure 3), while at a density of 40 fish. $\mathrm{L}^{-1}$, the predominance was shared between Copepoda and Cladocera, both consumed at level "b" (Figure 3).

In the relation to consumption of different zooplanktonic species supplied as food for the 21-day-old juveniles, Figure 2 shows that the species most consumed were those of Cladocera, Moina spp. and D. brevireme, and those of Copepoda in the form of Calanoida copepodid and naupliii, where these organisms were positively selected at all densities tested.

The Cladocera were those most consumed by the 28-day-old juveniles at all densities studied. This consumption decreased at a density of 40 fish. $\mathrm{L}^{-1}$, where the consumption of Copepoda increased in detriment of the consumption of Cladocera, resulting in a balanced consumption between these two groups (Figure 3). Cladocera and Copepoda showed a "b" level of consumption in the diet of the fish (Figure 3). There was a positive selection for Moina spp., D. brevireme and Calanoida copepodid at densities of 5 and 10 fish. $\mathrm{L}^{-1}$ and for all Cladocera available and Calanoida copepodid and naupliii at a density of 20 fish. $\mathrm{L}^{-1}$. At a density of 40 fish. $\mathrm{L}^{-1}$, the following were positively selected: Moina spp., D. brevireme, Argyrodiaptomus furcatus, Calanoida naupliii and copepodid.

\section{Discussion}

The factors that influenced the diet of the fish and existence or not of feeding selectivity are diverse, such as: the abundance and size of prey, ease of capture (including the prey's visibility and ability to escape), nutritional quality and competition, as well as the ontogeny of the fish (Gill, 2003; Roche and Rocha, 2005).

Although some species of fish have a diet that is very specific and defined, due to anatomic adaptations and choice of habitat (Lazzaro, 1991; Zavala-Camin, 1996; Fugi et al., 2001), there is evidence that especially for young fish juveniles, nutritional quality and energy gain are important factors (Hanson et al., 1997).

Planktonic organisms occupy a well-defined position in the transfer of energy in aquatic ecosystems, since the majority of species of fish utilise them as food during the first phases of development, where changes occur with respect to items ingested as the fish grow (SipaubaTavares, 1993; Ribeiro et al., 2001; Hayashi et al., 2002 Feiden et al., 2006; Marques et al., 2007).

In an aquatic environment, intra- and interspecific interactions determine the sources of food utilised by the individuals of a particular species. The availability of prey for a particular predator is the result of physiological and behavioural processes displayed by both. In experiments to estimate the availability and consumption of prey, Werner and Hall (1974) and Mittelbach (1981) found in species of the genus Lepomis that consumption was influenced on one hand by the size, shape, pigmentation, contrast, movement and ability of escape of the prey, while on the other hand, it was affected by the vision, preference and feeding behaviour of the predator (Zaret, 1980; Rincon and Lobon-Cervia, 1999; Gill, 2003; Pinto and Uieda, 2007; Rezende et al., 2011).

In relation to the size of organisms consumed, changes were observed with increase in age of the fish. Other authors, including Soares (2000) and Makrakis et al. (2005), also noted changes in the size of the most important items in the diets of juvenile forms of fish with increase in age, and found that differences with respect to the preferential food items for each species became more evident with individuals of advanced age.

Considering the feeding of the larvae of South American fish, it has been reported that there is a preference for the consumption of larger-sized zooplankton (Cladocera and copepods) and reduced consumption of Rotifera and Protozoa in the majority of the species studied (Prieto et al., 2006), which corroborates the behaviour displayed by the juvenile forms of Rhamdia quelen durring in the course of the present study, where a greater consumption 


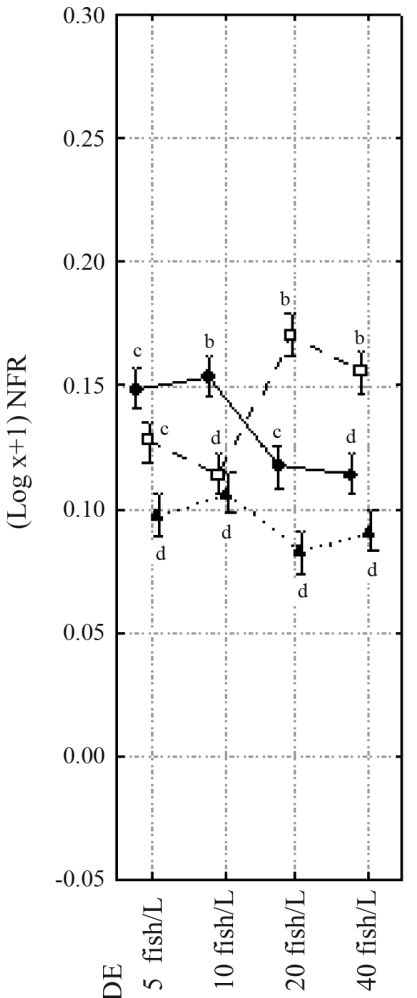

Age 7 days

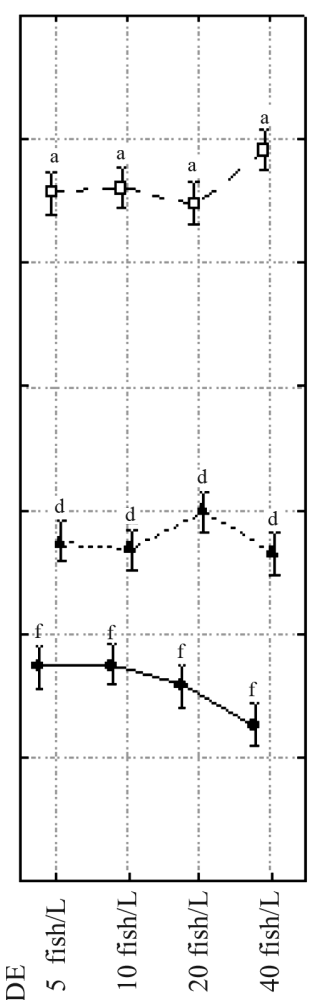

Age 14 days

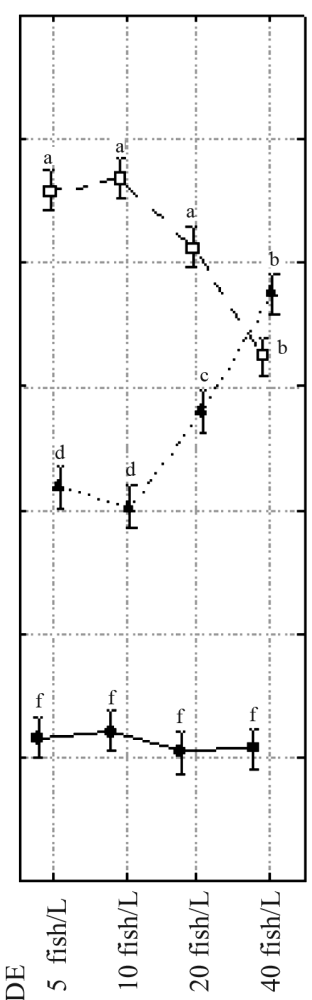

Age 21 days

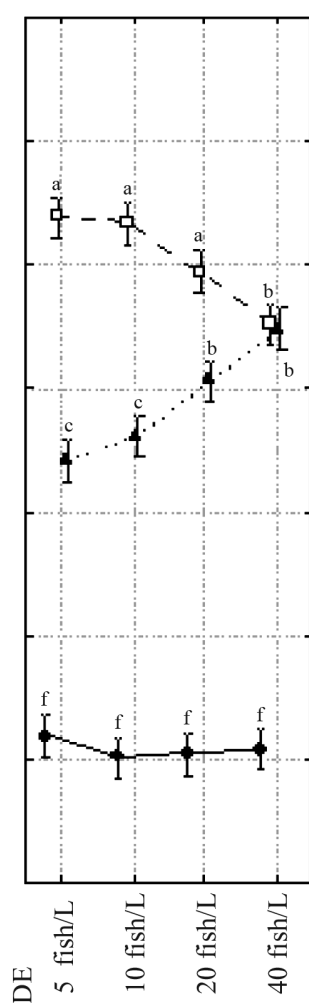

Age 28 days

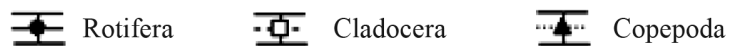

Figure 3 - Feeding selectivity index (NFR) of zooplanktonic groups consumed by juvenile forms of Rhamdia quelen at different ages and stocking densities (DS). Levels of consumption in decreasing order represented by the letters a-f.

Table 3 - Factorial analysis of variance of feeding selectivity indices (NRF) of juvenile forms of Rhamdia quelen (between 7 and 28 days of age) with regard to groups of zooplanktonic organisms present in the environments offered as food. Significant values denoted in bold $(\mathrm{p}<0.05)$.

\begin{tabular}{lcc}
\hline Effect & F & p \\
\hline Age*Group & 288.88 & $\mathbf{0 . 0 0 0 0 0 0}$ \\
Stocking density*Group & 15.84 & $\mathbf{0 . 0 0 0 0 0 0}$ \\
Age*Stocking density*Group & 14.94 & $\mathbf{0 . 0 0 0 0 0 0}$ \\
\hline
\end{tabular}

of Cladocera was observed. Priority for the consumption of larger zooplanktonic organisms in the beginning of exogenous feeding can be explained by the advantages of greater efficiency in the energy balance of larger prey (Werner and Hall, 1974; Warburton 2003).

Fregadolli (1993) observed in a study on the larval feeding selectivity of the fish pacu (Piaractus mesopotamicus Holmberg, 1887) and tambaqui (Colossoma macropomum Cuvier, 1816) that from the beginning of exogenous feeding, the larvae showed greater selection for prey that were larger and moved more, such as Cladocera. There was little selection for Rotifera, except
Table 4 - Scale of mean values referring to levels of consumption of zooplanktonic groups preyed upon by Rhamdia quelen during selectivity feeding and competition (decreasing order).

\begin{tabular}{lc}
\hline NFR $(\log \mathbf{x}+\mathbf{1})$ & Level of consumption \\
\hline $0.1963 \mid-0.2455$ & $\mathrm{a}$ \\
$0.1570 \mid-0.1963$ & $\mathrm{~b}$ \\
$0.1178 \mid-0.1570$ & $\mathrm{c}$ \\
$0.0785 \mid-0.1178$ & $\mathrm{~d}$ \\
$0.0393 \mid-0.0785$ & $\mathrm{e}$ \\
$0.0011 \mid-0.0393$ & $\mathrm{f}$ \\
\hline
\end{tabular}

in some cases with larger Rotifera. such as Brachionus calyciflorus (Pallas, 1766), which were more selected as alternative prey due to inefficiency in the capture of Cladocera, which were more able to escape compared to Rotifera.

The juvenile forms of Rhamdia quelen studied here showed a feeding preference influenced not only by their ages but also by the quantity of fish stocked in experimental units. Rotifera were positively selected only by 
the larvae of $R$. quelen at 7 days of age and predominated in the diet of individuals at densities of 5 and 10 fish. $\mathrm{L}^{-1}$. Some works suggest a relation between stocking density and efficiency in capture of prey. Piaia and Baldisserotto (2000) observed that jundia fry (R. quelen) submitted to a density of $0.74 \mathrm{~g} / \mathrm{L}$ remained in a group for the capture of food. However, when submitted a lower density $(0.18 \mathrm{~g} / \mathrm{L})$, they formed distinct and individual territories. Hecht and Uys (1997) found that higher stocking densities accelerated the response of juveniles of Clarias gariepinus (Burchell, 1822) to the presence of food in the tanks, that is, at the most elevated, the specimens ingested rapidly all the food, while at the lowest, ingestion was interrupted by periods of inactivity or agressions. It is likely that the reduced response to food at the low densities was due the fact that the specimens were busy maintaining territories (Hecht and Uys, 1997).

Pouey et al. (2011) found that Rhamdia quelen shows an inverse relation between stocking density and growth rate, due to the stress caused by the competition, but breeding of jundia at high densities is viable, since it does result in greater biomass despite showing a lower mean weight.

These results revealed that low stocking densities could have permitted the establishment of a more intense hierarchical process than at higher densities. High densities increase the frequency of confrontations and threats in territory disputes, up to the point that because the metabolic expenditure is very high, the fish abandon the defense of their territory and begin to group in schools (Jobling, 1994).

These factors can be considered in analysing the choice of food by the fish studied in this work, where the smaller and slower prey were more often captured at lower stocking density and age of $R$. quelen. These fish invested more energy in the defense of territories or simply had a slower response to the presence of larger prey, which led to the consumption of food items easier to capture such as Rotifera. However, higher stocking densities ( 20 and 40 fish. $\mathrm{L}^{-1}$ ), in conjunction with the formation of schools, decreased the chances of the escape of larger prey, which increased efficiency in the capture of Cladocera and copepods.

Authors such as Piedras and Pouey (2005) and Prieto et al. (2006) have demonstrated that groups of organisms such as Cladocera are preferred by the fish in comparison to copepods. This preference has been explained by body shape as well as mechanism of locomotion, which is more efficient among the copepods, facilitating their escape (Zaret, 1980).

However, at more advanced ages (14, 21 and 28 days), despite the selection for Cladocera remaining high and positive, there was positive selection for Calanoida copepodid, where at 28 days and DS of 40 fish. $\mathrm{L}^{-1}$, naupliii and Calanoida copepodid, besides adults of Argyrodiaptomus furcatus, were positively selected, reaching a proportion of capture similar to that of Cladocera (level of consumption "b"). This indicates that increase in mouth opening as well as the formation of schools could have increased the capture efficiency of larger and more agile organisms. Authors such as Makrakis et al. (2005) and Mai and Zaniboni-Filho (2005) observed that juvenile forms of carnivorous fish have a tendency to develop abilities such as greater mouth opening and caudal fins of greater propulsion, conferring maior swimming capacity and skills, among other physical and behavioural characteristicas that allow increasingly greater and more agile capture of prey as they grow.

\section{Conclusion}

The diet of the juvenile forms of Jundia (Rhamdia quelen) analysed was not linked to the availability of organisms present in the environment offered as food, since they demonstrated a high preference for Cladocera, despite the high availability of copepods. There was an interaction between age and the density at which they were stocked, influencing the feeding selectivity of juvenile forms on zooplanktonic organisms. At all ages, there was a feeding perference for Cladocera in relation to the other zooplanktonic groups. However, the presence of a lower number of competing animals (low DS) led to the foraging of smaller organisms, easier to capture, while the higher densities increased capture efficiency due to the formation of schools and more rapid response to the presence of food, which favoured the capture of items of greater energy value, even including organisms that were more difficult to catch due to their size and ability to escape.

\section{Acknowledgments}

The authors would like to thanks CAPES for a scholarship. We also thank Suziani R. Steffens for helping with sampling and laboratory experiments.

\section{References}

ARCIFA, MS., NORTHCOTE, TG. and FROEHLICH, O., 1991. Interative ecology of two cohabiting characin fishes (Astyanax fasciatus and Astyanax bimaculatus) in an eutrophic Brazilian reservoir. Journal of Tropical Ecol$o g y$, vol. 7, p. 257-268.

BEGON, M., TOWNSEND, CR. and HARPER, JL., 2006. Ecology: from individuals to ecosystems. Oxford: Blackwell Publishing. 759 p.

BOHN, T. and AMJNDSEN, PA., 2001. The competitive edge of an invading specialist. Ecology, vol. 82, p. 2150-2163.

BRANDÃO-GONÇALVES, L., OLIVEIRA, SA. and LIMA-JUNIOR, SE., 2010. Dieta da ictiofauna do córrego Franco - Mato Grosso do Sul, Brasil. Biota Neotropica, vol. 10, no. 2. http://www.biotaneotropica. org.br/v10n2/pt/abstract?article+bn00310022010.

CRIPPA, VEL., HAHN, NS. and FUGI, R., 2009. Food resource used by small-sized fish in macrophyte patches in ponds of the upper Paraná river floodplain. Acta Scientiarum Biological Sciences, vol. 31, no. 2, p. 119-125.

DEVRIES, DR. and STEIN, RA., 1992. Complex interation between fish and zooplankton: quantifying the role of an open-water planktivore. Canadian Journal of Fisheries and Aquatic Sciences, vol. 49, p. 1216-1227. 
DETMERS, JM. and STEIN, RA., 1992. Food consuption by larval gizzard shad: zooplankton effects and its implications for reseivor communities. Transactions of the American Fisheries Society, vol. 121, p. 494-507.

DIAS, TS. and FIALHO, CB., 2009. Biologia alimentar de quatro espécies simpátricas de Cheirodontinae (Characiformes, Characidae) do rio Ceará Mirim, Rio Grande do Norte. Iheringia. Série Zoologia, vol. 99, no. 3, p. 242-248.

ELMOOR-LOUREIRO, LMA., 1997. Manual de identificação de cladóceros límnicos do Brasil. Brasília: Universa. 155 p.

ESTEVES, KE. and ARANHA, JMR., 1999. Ecologia trófica de peixes de riachos. Oecologia Brasiliensis, vol 6, p. 157182.

FEIDEN, A., HAYASHI, C. and BOSCOLO, WR., 2006. Desenvolvimento de larvas de surubim-do-iguaçu (Steindachneridion melanodermatum) submetidas a diferentes dietas. Revista Brasileira de Zootecnia, vol. 35, no. 6, p. 2203-2210.

FREGADOLLI, CH., 1993. Seleção alimentar de larvas de pacu, Piaractus mesopotamicus Holmberg, 1887 e tambaqui, Colossoma macropomun Cuvier, 1818 em laboratório. Boletim Técnico do CEPTA, vol. 6, no. 1, p. 1-50.

FUGI, R., AGOSTINHO, AA. and HAHN, NS., 2001. Trophic morphology of five benthic-feeding fish species of a tropical floodplain. Brazilian Journal of Biology, vol. 61, p. 27-33.

GERKING, SD., 1994. Feeding Ecology of Fish. San Diego: Academic. 416p.

GILL, AB., 2003. The dynamics of prey choice in fish: the importance of prey size and satiation. Journal of Fish Biology, vol. 63, p.105-116.

HAHN, NS. and DELARIVA, RL., 2003. Métodos para avaliação da alimentação natural de peixes: o que estamos usando? INCI, vol. 28, no. 2, p.100-104.

HANSON, PC., JOHNSON, TB., SCHINDLER, DE. and KITCHELL, JF., 1997. Fish Bioenergetics 3.0. Madison Center for Limnology and Sea Grant Institute, University of Wisconsin. Available from: http://imnology. wis.Edu/research/bioenergetics/bioenergetics.html.

HAYASHI, C., SOARES, CM., GALDIOLI, EM. and DE SOUZA, SR., 2002. Uso de plâncton silvestre, fermento fresco e levedura desidratada na alimentação de larvas do cascudo chinelo, Loricariichthys platymetopon (Isbruchen and Nijssen, 1979) (Osteichthyes, Loricariidae). Acta Scientiarum, vol. 24, no. 2, p. 541-546.

HECHT, T. and UYS, W., 1997. Effect of density on the feeding and aggressive behaviour in juvenile African catfish, Clarias gariepinus. South African Journal of Science, vol. 93, p.537-541.

JOBLING, M., 1994. Fish bioenergetics. London: Chapman \& Hall, 294p.

KOSTE, W., 1978. Rotatoria: die Rädertiere Mitteleuropas Ein Bestimmungswerk begrüdet von Max Voigt. Berlin: Gebrüder Borntraeger. $637 \mathrm{p}$.

LAZZARO, X., 1991. Feeding convergence in South American and African zooplanktivorous cichlids Geophagus brasiliensis and Tilapia rendalli. Environmental Biology of Fishes, vol. 31, no. 3 p. 283 - 293.

LOWE-McCONNELL, RH., 1999. Estudos ecológicos de comunidade de peixes tropicais. São Paulo: Editora da Universidade de São Paulo. 535p.

LUZ, RK. and ZANIBONI, E., 2002. Larvicultura do mandiamarelo Pimelodus maculatus Lacépède, 1803 (Siluriformes: Pimelodidae) em diferentes densidades de estocagem nos primeiros dias de vida. Sociedade Brasileira de Zootecnia, vol. 31, no. 2, p. 560-565.

MAI, MG. and ZANIBONI-FILHO, E., 2005. Efeito da idade de estocagem em tanques externos no desempenho da larvicultura do dourado Salminus brasiliensis (Osteichthyes, Characidae) Acta Scientiarum. Animal Sciences, vol. 27, no. 2, p. 287-296.

MAKRAKIS, MC., NAKATANI, K., BIALETZKI, A., SANCHES, PV., BAUMGARTNER, G. and GOMES, LC., 2005. Ontogenetic shifts in digestive tract morphology and diet of fish larvae of the Itaipu reservoir, Brazil. Environmental Biology of Fishes, vol. 72, p. 99-107.

MARQUES, NR., HAYASHI, C., GALDIOLI, EM. and FERNANDES, CEB., 2007. Seletividade alimentar de organismos-alimento por formas jovens de pacu Piaractus mesopotamicus (Holmberg, 1887) e curimba Prochilodus lineatus (Valenciennes, 1836). Acta Scientiarum. Biological Sciences, vol. 29, no. 2, p. 167-176.

MITTELBACH, GG., 1981. Foraging efficiency and body size: a study of optimal diet and habitat use by Bluegills. Ecology, vol. 62, p.1370-1386.

O'GORMAN, JE., JACOB, U., JONSSON, T. and EMMERSON, MC., 2010. Interaction strengh, food web topology and relative importance of species in food webs. Journal of Animal Ecology, vol. 79, p. 682-692.

PALOHEIMO, JE., 1979. Índices of food type preference by a predator. Journal of Fisheries Research Board of Canada, vol. 36, p. 470-473.

PIAIA, R. and BALDISSEROTTO, B., 2000. Densidade de estocagem e crescimento de alevinos de Jundiá Rhamdia quelen (Quoy and Gaimard, 1824). Ciência Rural, vol. 30, no. 3, p. 509-513.

PIEDRAS, SRN. and POUEY, JLOF., 2005. Alimentação do peixe-rei (Odontesthes bonariensis, Atherinopsidae) nas lagoas Mirim e Mangueira, Rio Grande do Sul, Brasil Iheringia. Série Zoologia, vol. 95, no. 2, p.117-120.

PINTO, TLF. and UIEDA, VS., 2007. Aquatic insects selected as food for fishes of a tropical stream: Are there spatial and seasonal differences in their selectivity? Acta Limnologica Brasiliensia, vol. 19, p. 67-78.

POUEY, JLOF., PIEDRAS, SRN., ROCHA, CB., TAVARES, RA., SANTOS, JDM. and BRITTO, ACP., 2011. Desempenho produtivo de juvenis de jundiá (Rhamdia quelen) submetidos a diferentes densidades de estocagem. ARS Veterinaria, vol. 27, no. 4, p. 241-245.

PRIETO, M., DE LA CRUZ, L. and MORALES, M., 2006. Cultivo experimental del cladocero Moina $s p$ alimentado con Ankistrodesmus sp y Saccharomyces cereviseae. Revista MVZ Cordoba, vol. 11, no. 1, p. 705-714.

QIN, J. and CULVER, DA., 1996. Effect of larval fish and nutrient enrichment on plankton dynamics in experimental ponds. Hydrobiologia, vol. 321, p. 109-118.

REZENDE, CF., MAZZONI, R., CARAMASCHI, EP., RODRIGUES, D. and MORAES, M., 2011. Prey selection by two benthic fish species in a Mato Grosso stream, Rio de Janeiro, Brazil. Revista de Biología Tropical, vol. 59, no. 4, p. 1697-1706.

RIBEIRO, RP., HAYASHI, C. and MARTINS, EN., 2001. Hábito e seletividade alimentar de pós-larvas de piavuçú Leporinus macrocephalus (Garavello and Britski, 1988), submetidas a diferentes dietas em cultivos experimentais. Acta Scientiarum, vol. 23, no. 4, p.829-834.

RINCÓN, PA. and LOBÓN-CERVIÁ ,J., 1999. Prey-size selection by brown trout (Salmo trutta L.) in a stream in northern Spain. Canadian Journal of Zoology, vol. 77, p. 755765. 
ROCHA, O. and MATSUMURA-TUNDISI, T., 1976. Atlas do zooplâncton (Represa do Broa, São Carlos) I - Copepoda. São Carlos: Universidade Federal de São Carlos. 68p.

ROCHE, KF. and ROCHA, O., 2005. Aspectos da Predação por Peixes em Lagos e Represas, com Enfoque na Planctivoria. In ROCHE; KF. and ROCHA, O. (Eds.). Ecologia Trófica de Peixes com Ênfase na Planctivoria de Ambientes Lênticos de Água Doce no Brasil. São Carlos: Rima Editora. 136p.

RUSSO, MR. and HAHN, NS., 2006. Importance of zooplankton in the diet of a small fish in lagoons of theupper Paraná River floodplain, Brazil. Acta Limnologica Brasiliensia, vol. 18 , no. 4, p. 357-366.

RUSSO, MR., NAHN, NS. and PAVANELLI, CS., 2004. Resource partitioning of Bryconamericus Eigenmann, 1907 from the Iguaçu river Basin, Brazil. Acta Scientiarum. Biological Sciences, vol. 26, no. 4, p. 431-436.

SEGERS, H., 1995. Rotifera 2: The Lecanidae (Monogononta). The Hague:SPC Academics. 226 p. Guides to the identification of the microinvertebrates of the continental waters of the world, vol. 6 .

SHAHADY, TD., 1993. Impact of larval Dorosoma predation on Daphnia parvula dynamics. Freshwater Biology, vol. 30 , p. $279-287$.
SIPAÚBA-TAVARES, LH., 1993. Análise da seletividade alimentar em larvas de tambaqui (Colossoma macropomum) e tambacu (híbrido, pacu - Piaractus mesopotamicus e tambaqui - Colossoma macropomum) sobre organismos zooplanctônicos. Acta Limnologica Brasiliensia, vol. 6 , no. 1, p. 114-132.

SOARES, CM., HAYASHI, C. and GONGALVES, GS., 2000. Plâncton, Artemia sp, dieta artificial e suas combinações no desenvolvimento e sobrevivência do quinguio (Carassius auratus) durante a larvicultura. Acta Scientiarum, vol. 22, no. 2, p. 383-388.

STICKNEY, RR., 1994. Principles of aquaculture. New York: John Willey \& Sons, 502p.

WARBURTON, K., 2003. Learning of foraging skills by fish. Fish Fish, vol. 4, p. 203-215.

WEATHERLEY, AH., 1972. Growth and ecology of fish populations. London: Academic. 239p.

WERNER, E. and HALL, D., 1974. Optimal foraging and the selection of prey by the bluegill sunfish (Lepomis macrochirus). Ecology, vol. 55, p. 1042-1052.

ZARET, TM., 1980. Predation and freswater communities. New Haven: Yale University Press. 187p.

ZAVALA-CAMIN, LB., 1996. Introdução aos estudos sobre alimentação natural em peixes. Maringá: Eduem. 125p. 